\title{
Global Fisheries Management and Community Interest
}

\author{
Lei Zhang
}

check for updates

Citation: Zhang, L. Global Fisheries Management and Community Interest. Sustainability 2021, 13, 8586. https://doi.org/10.3390/su13158586

Academic Editors: Keyuan Zou and Yen-Chiang Chang

Received: 29 June 2021

Accepted: 27 July 2021

Published: 31 July 2021

Publisher's Note: MDPI stays neutral with regard to jurisdictional claims in published maps and institutional affiliations.

Copyright: (c) 2021 by the author. Licensee MDPI, Basel, Switzerland. This article is an open access article distributed under the terms and conditions of the Creative Commons Attribution (CC BY) license (https:/ / creativecommons.org/licenses/by/ $4.0 /)$.
Department of Law, Shandong University of Science and Technology, Qingdao 266590, China; skd996063@sdust.edu.cn; Tel.: +86-156-2116-0628

\begin{abstract}
The conservation of fishery resources is a common interest of the international community. In the 1990s, the global fisheries management system was formed based on the 1982 United Nations Convention on the Law of the Sea (LOSC). In order to achieve sustainable fisheries management, the international community also adopted a series of legally binding and non-binding policy instruments for the implementation of the global fisheries regime. The regional institutional framework was strengthened and expanded to offer broad coverage worldwide. Based on the analysis of the global fisheries management system, the article concludes that the current legal and policy instruments collectively provide a comprehensive framework for global fisheries management, but there still exist limits in addressing the challenges of fishery resources today. More effective implementation of the current legal system through better cooperation among States, as well as efficient coordination within and between national, regional and global institutions, is required.
\end{abstract}

Keywords: fishery resources; community interest; sustainable development; international cooperation

\section{Introduction}

For centuries, the international legal order had been developed with a relatively stable set of rules, mainly ensuring the respect of state sovereignty, but in the past few decades, there has been a shift in the focus of certain social relations between States [1] (p. 268). This has led to changes in international law, which has a number of new concepts to indicate the common interest in upholding human values or protecting common goods. For example, the Convention on Biological Diversity (CBD) affirms that "the conservation of biological diversity is a common concern of humankind" [2] (para. 3 of Preamble); the United Nations Framework Convention on Climate Change (UNFCCC) acknowledges that "the change in the Earth's climate and its adverse effects are a common concern of humankind" [3] (para. 1 of Preamble); the WTO law protects the community interest of promoting an essentially rule-based and fair world market, and the law of state responsibility reacts to serious breaches of common interests in human rights and humanitarian assistance.

The term "community interest" is not particularly clear and the great variation in its meaning, across regimes and even within each of them, can affect their identification in international law [4] (p. 38). However, there are two basic dimensions. Firstly, community interests are "common". These interests always correspond to the category of "public good" as defined in economics and are characterized by the fact of being "non-excludable". Any attack on the public good will necessarily affect the enjoyment of its benefits by all members of the community [4] (p. 39). The commonality of these common interests usually translates into the collective identity of their holders and/or bearers - that is, a "community", and, when the latter is universal, the "international community" [4] (p. 39). With the second dimension, the "community interest" leads to the consequence that all members of the international community as a whole have an interest in the protection of the common interests [5] (p. 332). The need to safeguard community interests triggered the generation of the concept of sustainability, which has been a feature in international legal relations for a long time [6]. 
Fishery resources are of great importance for food security and nutrition, economic growth through fish production and trade, as well as poverty alleviation and the creation of employment opportunities in the international community. According to a report published by the Food and Agriculture Organization (FAO), fish accounted for approximately $17 \%$ of animal protein consumed by the global population and provided approximately 3.3 billion people with almost $20 \%$ of their average per capita intake of animal protein in 2017 [7] (p. 67). In 2016, approximately 39 million people were engaged in the primary sector of capture fisheries [7] (p. 7). In the past, there were grounds for believing that fishery resources were limitless and could be exploited without loss to anyone else. However, biological, environmental, anthropological and many other factors have caused the situation to change. For example, overfishing and illegal, unreported and unregulated fishing (IUU fishing) are the main human factors and the adverse impact of climate change is difficult to underestimate.

In order to achieve the sustainability of fishery resources, it is important to pursue proper conservation policies towards the prevention of the exhaustion of these resources. The international response to the growing depletion of the world's fish stocks and the degradation of their habitats has been through the elaboration and adoption of three types of instruments. First, global fisheries treaties were adopted to address the conservation and management of fish stocks. Second, international voluntary instruments were adopted to promote a framework of principles and standards for responsible fisheries. Third, the regional institutional framework for the management of fishery resources was strengthened and expanded in coverage.

\section{Main Threats to Global Fisheries}

IUU fishing [8] as well as the environmental impact of climate change and marine pollution are major challenges to the sustainable development of fishery resources today. According to the annual report of the FAO, global capture fisheries production was 96.4 million tons in 2018 , and fisheries in the ocean provided $87.5 \%$ of the global total [7] (p. 6).

Overfishing and destructive fishing practices are recognized as the main threat to marine biodiversity in the areas within and beyond national jurisdiction (ABNJ) [9]. The adverse effects of fishing activities on the marine ecosystem mainly come from the overutilization of marine biological resources. When the degree of utilization of a certain biological population exceeds its maximum sustainable yield, it will cause the decline or even exhaustion of the targeted stocks and bycatch species, especially some species that are more susceptible to fisheries, such as marine mammals, sharks, turtles and seabirds, etc. [10] (p. 66). Overfishing not only has negative ecological consequences, but also reduces fish production in the long term, which subsequently has negative social and economic consequences. The world's marine fisheries had $34.2 \%$ of stocks classified as overfished in 2017 [7] (p. 54). It is estimated that rebuilding overfished stocks could increase fishery production by 16.5 million tons, which would certainly increase the contribution of marine fisheries to the food security and wellbeing of coastal communities [11] (p. 174).

The international community also recognizes IUU fishing as a major threat to the sustainability of fishery resources, to the livelihoods of the people that depend on them and to food security and marine ecosystems [8] (para. 1). It is well known that IUU fishing has escalated in the past 20 years, and it is found in all types and dimensions of fisheries, representing $20 \%$ of total catches per year, and undermines national and regional efforts to manage fisheries sustainably [12] (p. 12). Addressing IUU fishing and its impacts continues to be an essential part of fisheries governance. This issue is especially critical in developing countries, which lack the capacity and resources for effective monitoring, control and surveillance [13] (p. 82). Strong political will and concerted action by flag States, port States, coastal States and market States are required [13] (p. 82).

The ocean has absorbed $93 \%$ of the extra heat arising from the enhanced greenhouse effect [14] (p. 1). Given the essential role that the temperature plays in the biology and ecol- 
ogy of marine organisms, the speed of isotherm migration ultimately determines the speed at which populations must move, adapt or acclimate to changed sea temperatures [15] (p. 1667). Shifts in the distribution and abundance of large pelagic fish stocks will have the potential to create "winners" and "losers" among island States as catches of the transboundary fish stocks change among and within their exclusive economic zones (EEZs) [15] (p. 1702). For example, there has been an increase in fish stocks of warmer-water species near the Taiwan Strait, which were historically distributed throughout the South China Sea, partly as a result of warming conditions [15] (p. 1686). This is very likely to continue, although some fish stocks will eventually decline [15] (p. 1660). The ocean has also absorbed approximately $30 \%$ of atmospheric $\mathrm{CO}_{2}$ from human activities, which results in decreased ocean $\mathrm{pH}$ and carbonated ion concentrations and increased bicarbonate ion concentrations - that is, ocean acidification [15] (p. 1673). These two changes may exacerbate the existing overfishing and IUU fishing indirectly and challenge the sustainability of capture fisheries and aquaculture development.

The threats to fishery resources represent a potentially irreversible threat to human communities and thus require the widest possible cooperation by all States and their participation in an effective and appropriate response. To avert some of the worst impacts of fishery degradation and to realize sustainable development, the international community has taken actions, i.e., cooperation through global or regional agreements, as well as resolutions and declarations, on sustainable fisheries and marine ecological environment protection.

\section{Protection of Community Interests in the Global Fisheries Management System}

\subsection{Basic Legal Framework of Fisheries Management: The 1982 LOSC}

The LOSC provides a general legal framework for all kinds of activities in the seas and oceans. The preamble of the LOSC explicitly recognizes its aim of promoting the conservation of marine living resources, including fishery resources [16] (para. 4 of Preamble), and it established a basic framework for international cooperation in this field. There are two approaches applied for the conservation of the fishery resources in the LOSC, namely the zonal management approach and the species-specific approach.

\subsubsection{Zonal Management Approach}

Based on the LOSC, the ocean is divided into different zones within national jurisdiction, e.g., internal waters, territorial seas, exclusive economic zones and continental shelves, and areas beyond national jurisdiction, such as high seas. The LOSC governs human activities in the ocean according to the legal category of marine spaces, which is referred to as the "zonal management approach" [17] (p. 295). Under this approach, different rules apply to the conservation of marine living resources according to different jurisdictional zones.

In the areas within national jurisdiction, marine living resources are the important food supplies and mainstay of economy for coastal States. The coastal States not only enjoy the rights of exploring and exploiting the marine living resources, but also shoulder the responsibility of conserving and managing these resources [16] (Art. 61). It is estimated that approximately $90 \%$ of all commercially exploitable fish stocks are caught within 200 miles of the coast [18] (p. 162). For the conservation of living resources, the coastal States are required to ensure, through proper conservation and management measures, that the maintenance of living resources in the EEZ is not endangered by over-exploitation [16] (Art. 61). According to the LOSC, a coastal State shall determine the allowable catch of the living resources in its EEZ [16] (Art. 61) and determine its capacity to harvest the living resources of the EEZ; where the coastal State does not have the capacity to harvest the entire allowable catch, it shall, through agreements or other arrangements, give other States access to the surplus of the allowable catch [16] (Art. 62). The second obligation, i.e., optimum utilization, reflects the 1970s' concern of distant water fishing States that coastal States would drastically limit utilization of the fishery resources newly enclosed 
in their fisheries zones [19] (p. 6). Therefore, these States argued that it was necessary to establish an international obligation for the coastal States to ensure their utilization. Consequently, the coastal States are required to determine their capacity to harvest the living resources of the EEZ. However, the mechanism on the basis of the allowable catch presents considerable difficulties. For example, reliable scientific data are a prerequisite for allowable catch determination, while the data collection and analysis are complicated and costly; sometimes, it is difficult for developing countries to fulfill this obligation properly [18] (p. 283).

While the high seas are open to all States, every State enjoys the freedom of fishing [16] (Art. 87). At the same time, every State needs to adopt with respect to its national measures as well as cooperate with other States for the conservation of the living resources on the high seas [16] (Arts. 117, 118). Fishing on the high seas, to some degree, should rather be regarded as a privilege predicated on adherence to certain rules, not an absolute freedom [20] (p. 231). Increasing restrictions for the freedom of fishing on the high seas is a tendency, particularly in the LOSC, the United Nations Agreement for the Implementation of the Provisions of the 1982 LOSC relating to the Conservation and Management of Straddling Fish Stocks and Highly Migratory Fish Stocks (Fish Stocks Agreement) and regional fisheries management agreements.

The conservation of fishery resources involves both national interests and international community interests at the same time [5] (p. 364). Cooperation among States is one of the essential elements in the legal regime of high seas fisheries under the LOSC, and Article 117 requires "all States" to take, or to cooperate with other States in taking, such measures for their respective nationals as may be necessary for the conservation of the living resources of the high seas. Article 118 imposes upon States to cooperate with each other in the "conservation and management" of living resources in the areas of the high seas, and further requires States to cooperate as appropriate to establish sub-regional or regional fisheries organizations to this end.

\subsubsection{Species-Specific Approach}

The LOSC also adopts the species-specific approach to the conservation of marine living resources, under which conservation measures are to be determined according to specific categories of marine species such as shared fish stocks, straddling fish stocks, highly migratory species, marine mammals, anadromous stocks, catadromous species and sedentary species [16] (Arts. 63-68, 120). In order to implement the LOSC provisions, the Fish Stocks Agreement was adopted to provide a framework for cooperation in the conservation and management of straddling and highly migratory species [21]. The objective of the Fish Stocks Agreement is to ensure the long-term conservation and sustainable use of straddling fish stocks and highly migratory fish stocks through effective implementation of the relevant provisions of the LOSC [22] (Art. 2). This objective is achieved through the incorporation of a number of key State obligations, such as assessment of the impacts of fishing, other human activities and environmental factors on target stocks and ecologically related species or dependent or associated stocks; implementation and enforcement of conservation and management measures through effective monitoring, control and surveillance; and application of the ecosystem approach and precautionary approach [22].

The Fish Stocks Agreement reinforced States to cooperate with other States directly or through appropriate regional fisheries management organizations (RFMOs) or arrangements for the conservation and management of straddling fish stocks and highly migratory fish stocks, including cooperation for the establishment of new RFMOs where none exist in a particular region or sub-region [22] (Art. 8). States having a real interest in the fisheries concerned are encouraged by the Fish Stocks Agreement to become members of such RFMOs. It also provides that only States that are members of an RFMO, or those that agree to apply the conservation and management measures established by such an organization or arrangement, shall have access to the fishery resources to which the measures apply [22] (Art. 8). 
In general, the LOSC provides a basis for fisheries cooperation and legal certainty. As the most comprehensive codification of the international law of the sea so far, the LOSC has become the foundation of the international governance system for the conservation of fishery resources, with the strong support of the United Nations system.

\subsection{FAO's Efforts in the Global Fisheries Management}

As the primary management agency for marine fisheries, the FAO attaches great importance to the construction of sustainable fisheries. It has formulated and issued many fishery regulations, such as the Code of Conduct for Responsible Fisheries, Agreement on Port State Measures to Prevent, Deter and Eliminate IUU Fishing (PSMA) and a series of International Plan of Action (IPOAs) with regard to fishing issues, e.g., the International Plan of Action for the Management of Fishing Capacity and the International Plan of Action to Prevent, Deter and Eliminate IUU Fishing (IPOA-IUU). These instruments have played a key role in the conservation of marine fishery resources.

\subsubsection{Code of Conduct for Responsible Fisheries (FAO Code)}

In March 1991, the FAO Committee on Fisheries called for the development of new concepts for responsible, sustained fisheries. The FAO Code was drafted, negotiated and adopted by FAO member States to serve this purpose. It served as the basis for the development of the ecosystem approach to fisheries. This approach provides a framework for considering not only the ecological but also the social and economic aspects of sustainability and the governance context in which the fisheries sector operates [7] (p. 142). According to the data from the questionnaire on the implementation of the FAO Code sent every two years to all FAO member States, the percentage of States adopting an ecosystem approach to fisheries or a similar approach increased from $69 \%$ in 2011 to $79 \%$ in 2015 [13] (p. 82). However, the level of adoption varies among regions (see Figure 1).

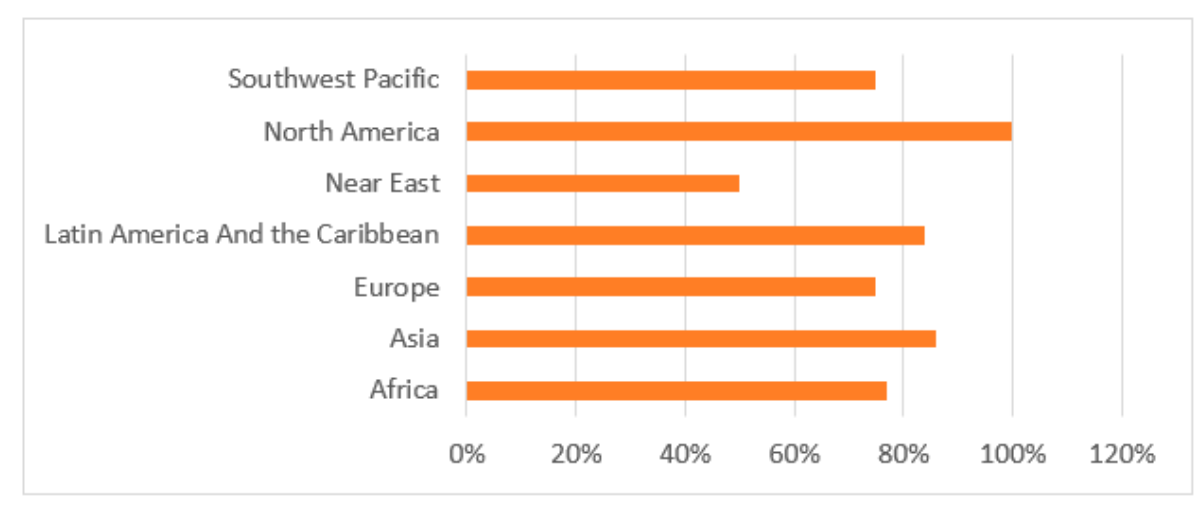

Figure 1. Percentage of States adopting ecosystem approach to fisheries/similar ecosystem approaches at the regional level. Source: FAO questionnaire on the implementation of the Code of Conduct for Responsible Fisheries, 2015 data.

A key problem of the FAO Code is its non-binding nature, which impedes its effectiveness due to the lack of legal force. However, it was incorporated into several important legally binding agreements, such as the FAO Agreement to Promote Compliance with International Conservation and Management Measures by Fishing Vessels on the High Seas (FAO Compliance Agreement) [23] (Art. 1.1). Recognizing the vulnerability inherent in such a management scheme, the FAO Compliance Agreement demands that party States "cooperate in a manner consistent with this Agreement and with international law" to prevent non-party States from undermining the FAO Compliance Agreement [24] (Art. 8).

\subsubsection{IPOA-IUU}

The IPOA-IUU was adopted by consensus at the 24th Session of the FAO Committee on Fisheries on 2 March 2001, and it was the first global instrument to introduce the 
expression of IUU fishing [8] (para. 3). Like the FAO Code, the IPOA-IUU is also a non-binding instrument. It was conceived as a comprehensive toolbox, which is a full range of tools that are available for use in a number of different situations to combat IUU fishing [25]. The commitments that FAO members have made under the IPOA-IUU, e.g., to enact national legislation to address all aspects of IUU fishing; to implement flag States' responsibility [26]; to implement monitoring, control and surveillance (MCS) measures; cooperative investigation of IUU fishing, expertise and technology exchange; harmonization of national measures and co-operation of MCS efforts; and to develop National Plans of Action (NPOAs) as soon as possible but no later than three years after the approval of the IPOA-IUU to achieve the objectives of the IPOA-IUU to full effect [24] (p. 14).

While the "hold all" terms of IUU fishing are stipulated in the IPOA-IUU, the range of measures available to non-flag States has been controversial [25]. In addition, there are ambiguities in the scope of unregulated fishing against which States can take action, such that certain unregulated fishing is not considered to be in violation of applicable international law and does not require the application of the measures envisaged under the IPOA-IUU [8] (para. 3.4). Faced with ambiguities in the scope of unregulated fishing, States other than the flag State might hesitate in taking necessary measures allowed under the IPOA-IUU.

\subsubsection{PSMA}

A major achievement in the global effort to combat IUU fishing, the binding FAO Agreement on PSMA, entered into force on 5 June 2016. The agreement provides an opportunity for States to collaborate and exchange information on fishing vessels and their activities, which can also be done through and with RFMOs. It creates a network that supports port States in combating IUU fishing, flag States in the control of their vessels, coastal States in protecting their fishery resources and market States in ensuring that products derived from IUU fishing do not enter their markets [27].

The PSMA sets conditions for the entry and use of ports by foreign fishing vessels [27]. It defines minimum international standards to be applied by port States in reviewing information prior to the vessels' entry into port; conducting inspections in their designated ports; taking measures against vessels found to have engaged in IUU fishing; and exchanging information with concerned States and international entities [27]. Inspection and compliance records of fishing vessels compiled through the information exchange mechanism under the PSMA could serve as a reliable resource for inclusion in national risk assessments and could help States to take appropriate action in cases of non-compliance with national, regional or international laws and regulations, including the prohibition or freezing of subsidies by the flag States concerned [13] (p. 98).

The global implementation of the PSMA would effectively establish "compliance checkpoints" at ports around the world for a large number of fishing vessels, especially those that operate in waters outside the jurisdiction of the flag State and seek entry into ports of other States. It is remarkable that the recognition of the requirements of developing States (developing States constitute the majority of parties and the majority of coastal States globally) is crucial, and parties of the PSMA emphasized the development of a framework to support developing States in their implementation of the agreement. A dedicated working group is tasked with addressing the requirements of developing States parties, including the administration of required funding to support capacity development efforts [28].

After the PSMA entered into force, some notable achievements have already been made. At the national level, a number of States made efforts, such as updating relevant legislation and increasing port inspection capacity, to implement the PSMA. At the regional level, the number of RFMOs that have adopted conservation and management measures regarding IUU fishing, and more specifically regarding port State measures, has continued to increase. Achievements in combating IUU are expected to grow with the increased 
uptake and implementation of the PSMA and as the global commitment to combat IUU fishing continues to build.

\subsection{New Developments of Regional Institutional Approach for Fisheries Management on the High Seas}

RFMOs are international organizations that serve as fora for the establishment, implementation and enforcement of legally binding management and conservation measures for fishing. RFMOs are currently the only legally mandated fisheries management bodies on the high seas, and States' commercial fishing fleets must abide by RFMOs' regulations in order to fish in these areas [29]. Many RFMOs are established under international conventions and have the authority to adopt legally binding provisions with regard to the conservation and management of fish stocks, and almost all of the high seas on Earth are now covered by at least one RFMO (see Appendix A) [30] (p. 1036).

The functions of RFMOs include the collection, analysis and dissemination of fisheries information, statistics and data; the establishment, implementation and regulation of conservation and management measures to ensure the long-term sustainability of fish stocks; the adoption of decision-making procedures; the establishment of monitoring, control, surveillance and enforcement measures and the adoption and establishment of participatory rights, etc. [22] (Art. 10). Like any international organizations, RFMOs' success in managing and conserving the resources under their jurisdiction depends on the political will of their member States [31] (p. 17).

The LOSC does not provide any information as to the role and mandate of RFMOs, while the Fish Stocks Agreement empowers RFMOs by giving them the mandate to fully conserve and manage highly migratory and straddling fish stocks under their area of competence and by imposing more stringent obligations on States. Under the Fish Stocks Agreement, only member States of these RFMOs are entitled to access the fishery resources under the organization's management [22] (Arts. 8, 17), but non-parties to the Fish Stocks Agreement have access to them under the freedom of fishing that is applicable on the high seas as they cannot be bound by a treaty to which they have not agreed to be bound. RFMOs have attempted to control activities by non-party vessels by giving incentives for cooperation, such as drawing the attention of non-parties to the activities of their vessels in the regulatory area of RFMOs [22] (Art. 17).

Current progress at the regional level has shown that in order to realize the conservation and sustainable use of biodiversity on the high seas, regional cross-institutional cooperation through coordinated efforts is necessary. The need for States and institutional cooperation both at the international and regional levels has been further highlighted in the UNGA Resolutions on Oceans and the Law of the Sea and in the Ad Hoc Open-Ended Informal Working Group to Study Issues Relating to the Conservation and Sustainable Use of Marine Biological Diversity Beyond Areas of National Jurisdiction (BBNJ Working Group) reports [32]. In this respect, cooperation and coordination between RFMOs and regional seas organizations in regional ocean governance is a new trend. The Collective Arrangement between the Protection of the Marine Environment in the North-East Atlantic (OSPAR) Commission and the North-East Atlantic Fisheries (NEAFC) Commission is a good example of such inter-institutional collaboration. The contracting parties adopted a stepped approach, starting with opening dialogues and mutual exchanges to learn about each other's mandates and activities through the cooperation ladder (Figure 2) [33]. 


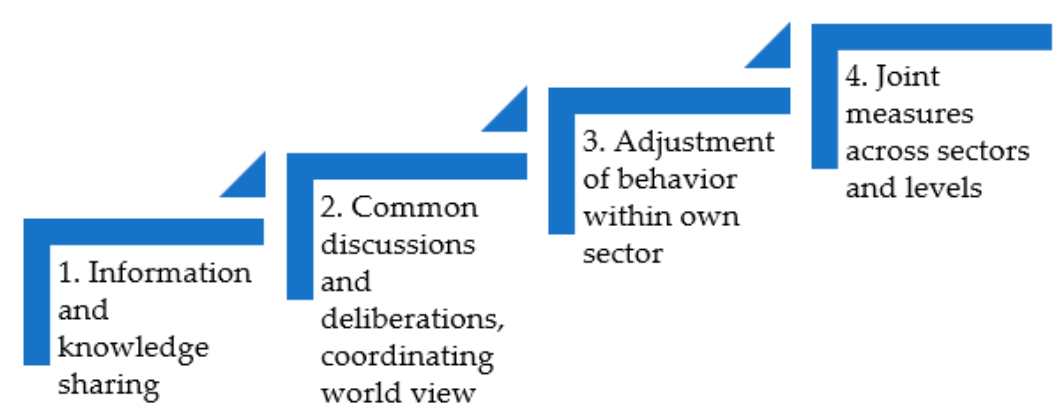

Figure 2. The cooperation ladder of OSPAR Commission and NEAFC Commission. Source: UNEP. Realizing Integrated Regional Oceans Governance-Summary of Case Studies on Regional CrossSectoral Institutional Cooperation and Policy Coherence. Regional Seas Reports and Studies No. 199.

As mentioned above, the need for cooperation between RFMOs and organizations that deal with the management of human activities in other sectors rises rapidly. Global guidance is available to ensure that area-based management tools, including the marine protected areas (MPAs), is integrated within broader fisheries management frameworks and follows good practices with regard to participatory approaches [13] (p. 80).

MPAs are vital to the sustainable development of oceans. They safeguard vulnerable species and ecosystems, conserve biodiversity and avert potential conflicts among users by delineating specific allowed activities [34]. A number of international policy instruments have recently been established in support of MPAs. For example, Aichi Target 11 [35] and Sustainable Development Goals (SDG) Target 14.5 [36], in particular, aimed for the designation of $10 \%$ of coastal and marine waters as protected areas by 2020 . According to the 2020 SDG Report, over 17\% (or 24 million square kilometers) of waters within national jurisdiction were covered by protected areas by the end of 2019 [37] (p. 60). The global mean percentage of each marine key biodiversity area covered by protected areas increased from $30.5 \%$ in 2000 to $46.0 \%$ in 2019 , but the majority of these sites still have incomplete or no MPA coverage [38].

The protection and conservation measures taken in MPAs include prohibition of, or restrictions on, navigation, dumping, fishing activities, seabed exploration, land-based pollution and access for tourism. In so-called "no take" zones, all forms of exploitation are prohibited. For example, in the South Orkney Islands Southern Shelf MPA, all types of fishing activities shall be prohibited within the defined area, with the exception of scientific fishing research activities agreed by the Commission for monitoring or other purposes on advice from the Scientific Committee [39] (Art. 2). The benefits of setting "no take" zones include maintenance of or an increase in fisheries productivity, maintenance of biodiversity and stock structure and protection of habitats [40] (p. 52). However, it is important to recognize that while MPAs have positive effects on biodiversity inside "notake" zones, efforts to secure the sustainability of fishery resources must build on a wider range of natural resource management interventions. Implemented in isolation, MPAs can result in the shifting of fishing pressure to areas that lack such management measures, or may have significant impacts on the livelihoods and food security of fisheries dependent communities [13] (p. 102). To avoid the negative consequences, MPAs should be combined with other management measures that control fishing effort outside the protected areas. Hence, MPAs must be an integral part of overall fisheries management plans and should not be viewed as a stand-alone fisheries management tool, unless they are the only viable option, such as in situations where the capacity to implement other forms of management is lacking [40] (p. 150).

\section{Achievements of Global Fisheries Management System}

Whereas the human causes for the threats to global fisheries vary, to a large extent, from the fundamental characteristics of fish, they are a common property and renewable natural resource that is incapable of being spatially confined [41] (p. 457). Today, however, 
it is widely acknowledged that fishery resources are finite and a common interest for human beings. How to realize the sustainable development of fishery resources becomes an important issue of international concern.

In addition to providing comprehensive multilateral rules to regulate the use of the seas, one of the most fundamental contributions of the LOSC has been acting as a new international law of global fisheries management [19] (p. 4). The fundamental redistribution of fishery resources between States has been laid down in the LOSC: the establishment of EEZ, which has ended the freedom of fishing within $200 \mathrm{~nm}$ along the coast with the richest fishery resources, is a typical example [42] (p. 41). Part V of the LOSC sets out the EEZ concept, under which the coastal States have "sovereign rights for the purpose of exploring and exploiting, conserving and managing the natural resources, whether living or non-living", as well as "the jurisdiction of protection and preservation of the marine environment" [16] (Art. 56). The EEZ has been described as an inheritance by the coastal States from the rest of the world: "Under the new regime of the seas, the world community has willed to the coastal States the bulk of living resources in waters off their shores." [43] (p. 1358). This is because the EEZ essentially brings under national jurisdiction large tracts of ocean space that previously belonged to the regime of the high seas. For this reason, the LOSC regulates that the coastal States not only enjoy the sovereign rights over the natural resources in EEZ, but fulfill two important obligations, namely conservation and optimum utilization [16] (Arts. 61, 62).

The traditional legal framework for fisheries management was based on the principle of free access to the living resources. The doctrine associated with this approach was the freedom of the high seas, which was the single operating principle under general international law for a long time [19] (p. 4). However, in the 1958 Geneva Conventions, freedom of high seas fishing is restrained by the requirement of due regard, the duty of cooperation and the duty of conservation [44]. By following the Geneva Conventions, the LOSC sets out more restrictions on high seas fishing, which altered the situation of utilization aspect dominated the concept of conservation. Furthermore, according to the traditional international law theory, a treaty is only legally binding on its contracting parties, but fisheries management rules have broken this limit. For example, the Fish Stocks Agreement does not only restrict the behavior of the contracting parties, but is also applicable to non-party States. Article 17 (1) provides:

"A State which is not a member of a sub-regional or regional fisheries management organization ...... and which does not otherwise agree to apply the conservation and management measures established by such organization or arrangement, is not discharged from the obligation to cooperate, in accordance with the Convention and this Agreement, in the conservation and management of the relevant straddling fish stocks and highly migratory fish stocks."

Moreover, the non-member State shall not authorize vessels flying its flag to engage in fishing operations for the straddling fish stocks or highly migratory fish stocks that are subject to the conservation and management measures established by such organization or arrangement [22] (Art. 17). In other words, the era of freedom of fishing on the high seas is ended, which makes fishing on the high seas completely under the joint management of the international community [45] (p. 276).

Based on the LOSC, other international instruments set out more specific rules especially for cooperation between States on high seas fishing: the IPOA-IUU covers flag, port, coastal and market State responsibilities, and envisages broad participation and coordination among States, as well as representatives from industry, fishing communities and NGOs, and the use of a comprehensive and integrated approach, so as to address all impacts of IUU fishing [25]; the Code of Conduct provides principles and standards applicable to the conservation, management and development of all aspects of fisheries, i.e., the capture, processing and trade of fishery products, fishing operations, aquaculture, fisheries research and the integration of fisheries into coastal area management [23] (Art. 
1.3). The international voluntary fisheries instruments have played a role supplementary to the LOSC, providing guidelines for the sustainable utilization of fishery resources.

Apart from fishery management measures on combating IUU fishing taken by the FAO and RFMOs, other instruments and international organizations of conserving marine living resources also assist in ensuring the sustainability of fishery resources and they include the IUCN, UNEP, the Convention on International Trade in Endangered Species of Wild Fauna and Flora (CITES) and the Convention on the Conservation of Migratory Species of Wild Animals (CMS) and the Ramsar Convention (wetlands). These international institutions have a strategic interest in both conservation and sustainable use, and have been increasingly working with the FAO to strengthen actions on addressing biodiversity considerations in fisheries, and to some extent, to give due recognition to fisheries' interests (and sustainable use) across their institutions [46] (p. 215).

In addition to the legal system of fisheries management, the formation of the intergovernmental mechanism for the management can be seen as another achievement. As the nature of global commons, the management of fishery resources requires cooperation between appropriate international and regional institutions to ensure multi-sectoral and integrated management [47] (p. 278). At the international level, the United Nations has convened several conferences on the subject of fisheries, and the FAO also included fisheries issues in the Agriculture (Fisheries) Ministerial Conference. Meanwhile, the RFMOs have been established globally, which represents the regional-level institutional model. As highlighted by Oude Elferink, much progress in the governance of high seas activities could be made at the sectoral and regional levels, incorporating both voluntary and binding approaches [48] (p. 254). Global ocean governance has gradually formed two paths in the process of practice, namely regionalism and globalism. They are both competing with each other and gradually integrating and complementing each other [49] (p. 6). On the one hand, the regional approach itself is inspired and promoted by the LOSC and other global ocean governance norms, rules and systems, and at the same time, it is an integral part of the international ocean governance framework to deal with issues such as marine environmental protection and fishery resources conservation; on the other hand, regional practices have formed a regional governance framework according to their own characteristics [49]. The regional approach has also been shown to engender a better legal commitment and policy convergence on behalf of States in the region, to be more cost-effective and more efficient in dealing with large-scale changes [50] (pp. 71, 79). However, it should be noted that the regional approach faces the interference of the competing influences of major powers and is more vulnerable to disputes or differences in interest claims among States within the region [49].

\section{Limits of the Global Fisheries Management System}

The fisheries management system has made positive contributions to the promotion of the sustainable development of fisheries. However, there still exist several essential limitations, which caused the trend of declining fishery resources.

The first essential limitation is in regard to the gaps between the management approaches and the characteristics of the marine ecosystem. The zonal management approach established by the LOSC is on the basis of distance from the coast, but ignores the fact that the ocean space and the natural resources within it are closely interrelated and need to be considered as a whole [20] (p. 223). The spatial scope of "man-made jurisdictional zones" does not always correspond to "ecologically defined space", which comprises the area where marine ecosystems extend [51] (p. 20). Moreover, the divergence between the law and nature raises considerable difficulty with regard to the conservation of straddling and highly migratory fish species. Due to their nature, these species do not respect manmade maritime boundaries. Hence, a clear-cut distinction between marine spaces under the coastal State's jurisdiction and marine spaces beyond such a jurisdiction is not always suitable for the conservation of these species [52] (p. 131). 
The LOSC imposed sovereign control over large sea areas that had traditionally been part of the international commons. In doing so, the LOSC attempted to balance the interests of the fishing States, derived from the freedom of high seas, with the interests of the world community in conserving and sustainably exploiting fisheries [53] (p. 226). However, the LOSC did not solve the problem of how to manage and conserve fish stocks that straddle a State's EEZ and either a neighbor State's EEZ or the high seas, nor disputed EEZs. This triggered an issue that the coastal State attached importance to the utilization of fishery resources rather than conservation, and the conservation measures of the coastal State are essentially characterized by its own economic and social interests in the EEZ [5] (p. 367).

Although the species-specific approach adopted by the LOSC and the Fish Stocks Agreement has played a supplementary function, it seems that the situation was not improved very much as the relevant provisions are too general to apply, which represents the second limitation of the fisheries management system [17] (p. 296). For example, according to the LOSC, States shoulder the obligation to cooperate on the conservation of fishery resources on the high seas, but the relevant provisions leave some ambiguities with regard to the content of the duty of cooperation [54] (p. 57). These provisions do not provide specific guidance describing how cooperation should be performed, nor do they explicitly state how to judge whether or not such obligation of cooperation was breached [55] (p. 26). In practice, cooperation may take various forms and need not necessarily to be pursued in a single form at any given time. The International Court of Justice (ICJ) in the Fisheries Jurisdiction cases required some forms of cooperation, such as a joint examination of conservation measures and entering into negotiations in giving effect to the duty of due regard [56] (pp. 31, 32, 201). Nevertheless, the obligations of contributing and exchanging available scientific information, fishing effort statistics and other data relevant to the conservation of fish stocks are treated as the most basic content. For example, parties to the PSMA have recognized the importance of swift and efficient information exchange; they have shared relevant information of foreign vessels seeking entry into, and using, their designated ports almost in real time to allow swift detection of IUU fishing. In order to operate effectively, the parties tasked the FAO with developing a global information exchange system (GIES) to facilitate the sharing of information relevant to the PSMA, and established an informal working group to provide guidance on the elaboration of the system [57]. The FAO has developed pilot PSMA applications for States to upload their designated ports and national contact points. As of February 2020, 49 States had uploaded their national contact points, and 39 States had uploaded information on their designated ports [7] (p. 110).

The third limitation relates to the issues of binding force and the implementation of relevant international instruments. The voluntary instruments adopted by the FAO, such as the FAO Code and the IPOAs, do make great efforts in the global fisheries management, but their non-binding nature does significantly impede their effectiveness due to the lack of legal force. Thus far, efforts to achieve a fine balance between encouraging widespread international participation and the effective implementation of the guidelines and measures outlined in these voluntary instruments have largely failed [19] (p. 17). As mentioned above, the FAO Code has been incorporated into the FAO Compliance Agreement with mixed results. This approach might be an example to solve the problem of the vulnerability inherent in such voluntary instruments, and strike a traditional balance between mare liberum and environmental stewardship [53] (p. 235).

\section{Conclusions}

The conservation and management of fishery resources is an indispensable component of the protection of community interests in international law, as well as involving the interests of the survival and development of human beings, which is not only for the present but also for future generations. The legal framework governing the conservation of fishery resources in the LOSC relies essentially on the zonal management approach and the species-specific approach, though these two approaches comprise limitations. For 
filling the regulatory gaps, the international community has endeavored to negotiate more specific fishery agreements and non-binding policy instruments, as well as to apply management tools, i.e., MPAs, which jointly compose the governance regime for the sustainable development of fisheries. At present, it can no longer deny that the survival of mankind as a whole should be closely aligned with the protection of community interests, and the existing management system makes great efforts to achieve it. One of the outstanding achievements is that the era of freedom of fishing on the high seas is ended, which makes fishing on the high seas completely under the management of the international community.

The international community endeavored to build a governance regime for the global commons on the paradigm of consensus. However, this assumes that all players are negotiating in good faith towards a common goal, rather than protecting their short-term national interests. "Free-riders" outside the system or progress-blocking within the system will be inconsistent with the fundamental duty to cooperate, and make the governance regime less effective. The traditional fisheries management system is State-centered. No matter the General Assembly' resolutions or the rules adopted by FAO, or the directives of RFMOs, are based on the State's sovereignty commitments. However, it proves that it is not effectively working. The quest for effective mechanisms for the global fisheries management will continue to be an important topic in international law. In order to protect the community interest of human beings, a multi-governing model is needed, i.e., the participation of stakeholders, such as the government organizations, NGOs, companies and individuals, in addition to nation States.

Funding: This research was funded by China's National Social Sciences Foundation (18VHQ002).

Institutional Review Board Statement: Not applicable.

Informed Consent Statement: Not applicable.

Acknowledgments: The author is grateful to Keyuan Zou for his insightful comments and suggestions towards improving this manuscript.

Conflicts of Interest: The author declares no conflict of interest. 


\section{Appendix A}

Table A1. Regional fishery bodies fact sheet.

\begin{tabular}{|c|c|c|c|}
\hline & Name & Area of Competence & Species and Stocks Coverage \\
\hline \multirow{6}{*}{ Continents } & $\begin{array}{c}\text { Central Asian and Caucasus Regional Fisheries and } \\
\text { Aquaculture Commission (CACF) }\end{array}$ & \multirow{2}{*}{$\begin{array}{l}\text { The inland waters and areas within the territorial } \\
\text { boundaries of the States of Central Asia } \\
\text { Inland waters of Lake Chad Waters and Lake Chad } \\
\text { Basin }\end{array}$} & All living aquatic resources \\
\hline & Lake Chad Basin Commission (CBLT) & & The waters and transboundary water resources \\
\hline & $\begin{array}{l}\text { Commission for Small-Scale and Artisanal Fisheries and } \\
\text { Aquaculture of Latin America and the Caribbean } \\
\text { (COPPESAALC) }\end{array}$ & $\begin{array}{l}\text { Marine coastal and inland waters of member } \\
\text { countries }\end{array}$ & All species \\
\hline & Commission is European Inland Fisheries and & \multirow{3}{*}{$\begin{array}{c}\text { Inland waters of member countries } \\
\text { The Lake Tanganyika Basin } \\
\text { Lake Victoria } \\
\text { The Mekong River Basin } \\
\text { The inland territories and national waters of } \\
\text { member states }\end{array}$} & All species \\
\hline & $\begin{array}{l}\text { Lake Tanganyika Authority (LTA) } \\
\text { Lake Victoria Fisheries Organization (LVFO) } \\
\text { Mekong River Commission (MRC) }\end{array}$ & & $\begin{array}{c}\text { Littoral and pelagic species of the Lake Tanganyika } \\
\text { All aquatic species } \\
\text { All living resources }\end{array}$ \\
\hline & The Aquaculture Network for the Americas (RAA) & & All commercially farmed aquatic species \\
\hline \multirow{3}{*}{$\begin{array}{l}\text { Global and } \\
\text { trans-ocean }\end{array}$} & $\begin{array}{c}\text { Agreement on the Conservation of Albatrosses and } \\
\text { Petrels (ACAP) }\end{array}$ & \multirow{2}{*}{$\begin{array}{c}\text { All the areas of land or water that any albatross or } \\
\text { petrel inhabits, stays in temporarily, crosses or } \\
\text { over-flies at any time on its normal migration routes } \\
\text { Southern Ocean }\end{array}$} & 22 species of albatross and 8 species of petrels \\
\hline & $\begin{array}{c}\text { Commission for the Conservation of Antarctic Marine } \\
\text { Living Resources (CCAMLR) }\end{array}$ & & $\begin{array}{l}\text { All marine living resources, except for the management } \\
\text { or harvesting of whales and seals }\end{array}$ \\
\hline & $\begin{array}{c}\text { International Whaling Commission (IWC) } \\
\text { Central America Fisheries and Aquaculture Organization } \\
\text { (OSPESCA) }\end{array}$ & $\begin{array}{l}\text { Global } \\
\text { National waters, inland waters and EEZs of its } \\
\text { member States }\end{array}$ & $\begin{array}{c}\text { Whales } \\
\text { Marine capture, inland capture and aquaculture fish } \\
\text { stocks of member States }\end{array}$ \\
\hline
\end{tabular}


Table A1. Cont.

\section{Name}

Asia-Pacific Fishery Commission (APFIC)

Convention on the Conservation and Management of Pollock Resources in the Central Bering Sea (CCBSP) Pacific Islands Forum Fisheries Agency (FFA) Inter-American Tropical Tuna Commission (IATTC)

International Pacific Halibut Commission (IPHC)

North Pacific Anadromous Fish Commission (NPAFC)

North Pacific Fisheries Commission (NPFC)

Pacific Ocean

North Pacific Marine Science Organization (PICES)

Pacific Salmon Commission (PSC)

Southeast Asian Fisheries Development Center (SEAFDEC)

Secretariat of the Pacific Community (SPC)

South Pacific Regional Fisheries Management organization (SPRFMO)

Network of Aquaculture Centers in Asia-Pacific (NACA) Western and Central Pacific Fish Stocks Commission (WCPFC)

Area of Competence

Asia-Pacific area, including the Bay of Bengal

High seas of the Bering Sea

High seas, National waters

Eastern Pacific Ocean

High seas, National waters

High seas of North Pacific Ocean and its adjacent seas

High seas area of the North Pacific Ocean

The temperate and sub-Arctic region of the North Pacific Ocean and its adjacent seas

Transboundary rivers and salmon-spawning rivers belonging to one party, where the salmon are subject to capture by the other party

SEAFDEC does not have a defined geographical area of competence

All the Pacific Island countries and territories which, together with France, USA, New Zealand and Australia, comprise the member States

High seas of the Pacific Ocean

The inland territories of member states Western Central Pacific Ocean

\section{Species and Stocks Coverage}

Marine, fresh and brackish water species, including coastal and high seas stocks

$$
\text { Alaska pollock }
$$

Tuna and tuna-like species

Tuna and tuna-like species and other species of fish taken by vessels fishing for tunas and tuna-like species Pacific halibut

Chum salmon, Coho salmon, pink salmon, sockeye salmon, Chinook salmon, cherry salmon, steelhead trout Fish, mollusks, crustaceans and other marine species caught by fishing vessels within the Convention Area

All living resources

All Pacific salmon stocks

All fishery resources

All fishery resources

All species except highly migratory species, sedentary species which are subject to national jurisdiction, anadromous and catadromous species, marine mammals/reptiles and sea birds

All commercially farmed aquatic species Highly migratory fish stocks 
Table A1. Cont.

\begin{tabular}{|c|c|c|c|}
\hline & Name & Area of Competence & Species and Stocks Coverage \\
\hline \multirow{5}{*}{ Indian Ocean } & $\begin{array}{c}\text { Bay of Bengal Programme Inter-Governmental } \\
\text { Organization (BOBP-IGO) }\end{array}$ & $\begin{array}{c}\text { EEZ of the member States and contiguous areas } \\
\text { beyond national jurisdiction }\end{array}$ & All marine fish stocks \\
\hline & Indian Ocean Tuna Commission (IOTC) & $\begin{array}{l}\text { Indian Ocean and adjacent seas north of the Antarctic } \\
\text { Convergence }\end{array}$ & Tuna and tuna-like species \\
\hline & Regional Commission for Fisheries (RECOFI) & National waters in the region & All living marine resources \\
\hline & Southern Indian Ocean Fisheries Agreement (SIOFA) & High seas in the region & $\begin{array}{l}\text { Resources of fish, molluscs, crustaceans and other } \\
\text { sedentary species, excluding: (i) sedentary species subject } \\
\text { to the coastal States; (ii) highly migratory species }\end{array}$ \\
\hline & $\begin{array}{l}\text { Southwest Indian Ocean Fisheries Commission } \\
\text { (SWIOFC) }\end{array}$ & Indian Ocean & All living marine resources \\
\hline \multirow{14}{*}{ Atlantic Ocean } & $\begin{array}{l}\text { Fishery Committee for the Eastern Central Atlantic } \\
\text { (CECAF) }\end{array}$ & Atlantic Ocean & All living marine resources \\
\hline & $\begin{array}{l}\text { Ministerial Conference on Fisheries Cooperation among } \\
\text { African States Bordering the Atlantic (COMHAFAT) }\end{array}$ & EEZ of the member States & All marine living resources \\
\hline & $\begin{array}{l}\text { Regional Fisheries Commission for the Gulf of Guinea } \\
\text { (COREP) }\end{array}$ & National waters, inland waters of member States & All marine living resources \\
\hline & Caribbean Regional Fisheries Mechanism (CRFM) & National waters, inland waters of member States & All fisheries resources \\
\hline & $\begin{array}{l}\text { Joint Technical Commission of the Maritime Front } \\
\text { (CTMFM) }\end{array}$ & EEZ of the member States & $\begin{array}{l}\text { The main fishery resources are white mouth croaker, } \\
\text { argentine hake and stripped weakfish }\end{array}$ \\
\hline & $\begin{array}{l}\text { Fisheries Committee for the West Central Gulf of Guinea } \\
\text { (FCWC) }\end{array}$ & National waters of member States & All fisheries resources \\
\hline & $\begin{array}{c}\text { Joint Norwegian-Russian Fisheries Commission } \\
\text { (JointFish) }\end{array}$ & Barents Sea and Norwegian Sea & Cod, capelin, Greenland halibut, king crab \\
\hline & Northwest Atlantic Fisheries Organization (NAFO) & North-West Atlantic Ocean & $\begin{array}{l}\text { All marine fisheries resources, except salmon, tunas, } \\
\text { marlins, whales and sedentary species }\end{array}$ \\
\hline & North Atlantic Marine Mammal Commission (NAMMCO) & The North Atlantic Ocean & All species of cetaceans and pinnipeds \\
\hline & $\begin{array}{l}\text { North Atlantic Salmon Conservation Organization } \\
\text { (NASCO) }\end{array}$ & & Atlantic salmon \\
\hline & North-East Atlantic Fisheries Commission (NEAFC) & $\begin{array}{l}\text { Those parts of the Atlantic and Arctic Oceans and } \\
\text { their dependent seas which lie north of } 36^{\circ} \text { north } \\
\text { latitude and between } 42^{\circ} \text { west longitude and } 51^{\circ} \text { east } \\
\text { longitude (with excluding) }\end{array}$ & $\begin{array}{l}\text { All resources of fish, molluscs, crustaceans and including } \\
\text { sedentary species, excluding other international agreements, } \\
\text { highly migratory species and anadromous stocks }\end{array}$ \\
\hline & South-East Atlantic Fisheries Organization (SEAFO) & South East Atlantic Ocean & $\begin{array}{l}\text { Resources of fish, molluscs, crustaceans and other } \\
\text { sedentary species, excluding: (i) sedentary species subject } \\
\text { to the coastal States; (ii) highly migratory species }\end{array}$ \\
\hline & Sub-Regional Fisheries Commission (SRFC) & National waters of member States & All fisheries resources \\
\hline & $\begin{array}{l}\text { Western Central Atlantic Fishery Commission } \\
\text { (WECAFC) }\end{array}$ & Western Central Atlantic & All living marine resources \\
\hline
\end{tabular}




\section{References}

1. Simma, B. Universality of International Law from the Perspective of a Practitioner. Eur. J. Int. Law 2009, 20, 265-297. [CrossRef]

2. Convention on Biological Diversity. Available online: http://www.un-documents.net/cbd.htm (accessed on 29 July 2021).

3. United Nations Framework Convention on Climate Change. Available online: http://unfccc.int/files/essential_background/ background_publications_htmlpdf/application/pdf/conveng.pdf (accessed on 29 July 2021).

4. Besson, S. Community Interests in International Law: Whose Interests Are They and How Should We Best Identify Them? In Community Interests across International Law; Benvenisti, E., Nolte, G., Eds.; Oxford University Press: Oxford, UK, 2018.

5. Tanaka, Y. Protection of Community Interests in International Law: The Case of the Law of the Sea. In Max Planck Yearbook of United Nations Law; Koninklijke Brill N.V.: Leiden, The Netherlands, 2011; Volume 15, pp. 329-375. Available online: https://www.mpil.de/files/pdf3/mpunyb_07_Tanaka_15.pdf (accessed on 29 July 2021).

6. Many treaties and international instruments, as well as decisions of international courts, have supported the concept of sustainable development and the principle that states have the responsibility to ensure the sustainable use of natural resources. Its application has been recognized in relation to all parts of the world. See e.g., Declaration on Establishment of the Arctic Council, Agreements on Cooperation for the Sustainable Development of the Mekong River Basin, Southeast Atlantic Fisheries Convention, North-East Pacific Convention, Southern Indian Ocean Fisheries Agreement, Agreement on Port State Measures to Prevent, Deter and Eliminate Illegal, Unreported and Unregulated Fishing, etc. Sands, P.; Peel, J.; Fabra, A.; MacKenzie, R. In Principles of International Environmental Law, 3rd ed.; Cambridge University Press: Cambridge, UK, 2012.

7. Food and Agriculture Organization. The State of World Fisheries and Aquaculture 2020: Sustainability in Action; FAO: Rome, Italy, 2020.

8. Food and Agriculture Organization. International Plan of Action to Prevent, Deter and Eliminate Illegal, Unreported and Unregulated Fishing (IPOA-IUU); FAO: Rome, Italy, 2001.

9. Agenda 21, Rio de Janeiro. 13 August 1992. Available online: https://sustainabledevelopment.un.org/content/documents/ Agenda21.pdf (accessed on 29 July 2021).

10. Huang, S.; Shao, H. Development Trends and Features of Global Marine Fisheries Governance. Pac. J. 2018, 26, 65-78. (In Chinese)

11. Ye, Y.; Cochrane, K.; Bianchi, G.; Willmann, R.; Majkowski, R.; Tandstad, M.; Carroci, F. Rebuilding Global Fisheries: The World Summit Goal, Costs and Benefits. Fish Fish. 2013, 14, 174-185. [CrossRef]

12. Food and Agriculture Organization. Achieving Blue Growth: Building Vibrant Fisheries and Aquaculture Communities; FAO: Rome, Italy, 2018.

13. Food and Agriculture Organization. The State of World Fisheries and Aquaculture 2018: Meeting the Sustainable Development Goals; FAO: Rome, Italy, 2018.

14. Bahri, T.; Barange, M.; Moustahfid, H. Climate Change and Aquatic Systems. In Impacts of Climate Change on Fisheries and Aquaculture: Synthesis of Current Knowledge, Adaptation and Mitigation Options; FAO Fisheries and Aquaculture Technical Paper No. 627; FAO: Rome, Italy, 2018.

15. Working Group II to the Fifth Assessment Report of the Intergovernmental Panel on Climate Change Climate. Change 2014: Impacts, Adaptation, and Vulnerability; Cambridge University Press: Cambridge, UK, 2014.

16. United Nations Convention on the Law of the Sea. Available online: https://www.un.org/Depts/los/convention_agreements/ texts/unclos/closindx.htm (accessed on 29 July 2021).

17. Tanaka, Y. The Changing Approaches to Conservation of Marine Living Resources in International Law. Heidelb. J. Int. Law 2011, 71, 291-330.

18. Churchill, R.; Lowe, V. Law of the Sea, 3rd ed.; Manchester University Press: Manchester, UK, 1999.

19. Tsamenyi, M.; Manarangi-Trott, L.; Rajkumar, S. The International Legal Regime for Fisheries Management. In Proceedings of the UNEP Workshop on Fisheries Subsidies and Sustainable Fisheries Management, Geneva, Switzerland, $26-27$ April 2004.

20. Gjerde, K.M. High Seas Fisheries Governance: Prospects and Challenges in the 21st Century. In The World Ocean in Globalization; Vidas, D., Schei, P.J., Eds.; Martinus Nijhoff Publishers: Leiden, The Netherlands, 2011.

21. Overview of the Fish Stock Agreement. Available online: https://www.un.org/Depts/los/convention_agreements/convention_ overview_fish_stocks.htm (accessed on 20 June 2021).

22. Fish Stocks Agreement. Available online: https://documents-dds-ny.un.org/doc/UNDOC/GEN/N95/274/67/PDF/N9527467 .pdf?OpenElement (accessed on 29 July 2021).

23. Code of Conduct for Responsible Fisheries. Available online: http://www.fao.org/3/v9878e/v9878e00.htm (accessed on 29 July 2021).

24. Agreement to Promote Compliance with International Conservation and Management Measures by Fishing Vessels on the High Seas. Available online: http:/ / www.fao.org/3/X3130m/X3130E00.htm (accessed on 29 July 2021).

25. Food and Agriculture Organization, IUU Fishing. Available online: http://www.fao.org/iuu-fishing/international-framework/ ipoa-iuu/en/ (accessed on 20 June 2021).

26. FAO. Includes developing and keeping record of fishing vessels, effective fishing authorization procedures, imposition of sufficiently severe penalties so as to discourage nationals engaging in IUU activities and avoiding subsidies to companies, vessels and people engaged in IUU fishing. In International Plan of Action to Prevent, Deter and Eliminate Illegal, Unreported and Unregulated Fishing (IPOA-IUU); FAO: Rome, Italy, 2001. 
27. Agreement on Port State Measures to Prevent, Deter and Eliminate IUU Fishing. Available online: http://www.fao.org/ fileadmin/user_upload/legal/docs/037t-e.pdf (accessed on 29 July 2021).

28. In 2017, to Support Developing States (Irrespective of Whether They Are Parties to the PSMA) in Their Efforts to Combat IUU Fishing, FAO Launched a Global Capacity Development Umbrella Program: "Support for the Implementation of the 2009 Port State Measures Agreement and Complementary Instruments to Combat IUU Fishing". This Program Assists States in Strengthening Their Policy and Legal Frameworks, Institutional Setup and Enforcement Capacity, as Well as Their Monitoring, Control and Surveillance Systems and Operations, Placing Them in a Better Position to Combat IUU Fishing Effectively. Available online: https://www.un.org/depts/los/general_assembly/contributions_2020/FAO.pdf (accessed on 29 July 2021).

29. In the Resolution 69/292 of 19 June 2015, the United Nations General Assembly Decided to Develop an International Legally Binding Instrument under LOSC on the Conservation and Sustainable Use of Marine Biological Diversity of ABNJ. The BBNJ Process Constitutes an Important Driver in the Development of Multisectoral Governance in The High Seas, Where RFMOs Have a Recognized Role. Available online: https:/ / documents-dds-ny.un.org/doc/UNDOC/GEN/N15/187/55/PDF/N1518755.pdf? OpenElement (accessed on 29 July 2021).

30. Cullis-Suzuki, S.; Pauly, D. Failing the High Seas: A Global Evaluation of Regional Fisheries Management Organizations. Mar. Policy 2010, 34, 1036-1042. [CrossRef]

31. FAO Fisheries and Aquaculture Department. The State of World Fisheries and Aquaculture 2012; FAO: Rome, Italy, 2012.

32. United Nations General Assembly. Oceans and the Law of the Sea: Report of the Secretary-General; GA Res 67/78, 67th session, Agenda Item 75 (a), A/67/78. 18 April 2013. Available online: https://www.un.org/en/development/desa/population/ migration/generalassembly/docs/globalcompact/A_RES_67_78.pdf (accessed on 29 July 2021).

33. Ásmundsson, S.; Corcoran, E. The Process of Forming a Cooperative Mechanism between NEAFC and OSPAR. UNEP Regional Seas Reports and Studies No. 196. 2015. Available online: https://www.ospar.org/documents?v=35111 (accessed on 29 July 2021).

34. IUCN. Guidelines for Protected Area Management Categories; IUCN: Gland, Switzerland; Cambridge, UK, 1994.

35. Aichi Biodiversity Targets. Available online: https:/ / www.cbd.int/sp/targets/ (accessed on 20 June 2021).

36. SDG Target 14.5. Available online: https://www.un.org/sustainabledevelopment/oceans/\#tab-260cea69595a56b794f (accessed on 20 June 2021).

37. United Nations. The Sustainable Development Goals Report 2020; Sales No. E.20.1.7. 2020. Available online: https://unstats.un. org/sdgs/report/2020/The-Sustainable-Development-Goals-Report-2020.pdf (accessed on 29 July 2021).

38. According to the Progress Summary for SDG Targets with a 2020 Deadline, the Target of "Conserve at Least $10 \%$ of Coastal and Marine Areas" Is Evaluated as "Achieved or on Track to Being Achieved". Available online: https://www.un.org/ sustainabledevelopment/oceans/\#tab-260cea69595a56b794f (accessed on 29 July 2021).

39. Conservation Measure 91-03 (2009): Protection of the South Orkney Islands Southern Shelf. Available online: https://www. ccamlr.org/sites / default/ files/91-03_9.pdf (accessed on 29 July 2021).

40. Food and Agriculture Organization. Fisheries Management: 4. Marine Protected Areas and Fisheries; FAO Technical Guidelines for Responsible Fisheries: Suppl. 4; FAO: Rome, Italy, 2011.

41. Monlenaar, E.J. Participation, Allocation and Unregulated Fishing: The Practice of Regional Fisheries Management Organizations. Int. J. Mar. Coast. Law 2003, 18, 457-480. [CrossRef]

42. Wei, D. A Study on the Issues of the International Governance System of Marine Fishery Resources Conservation. J. Ocean Univ. China (Soc. Sci.) 2016, 5, 39-45. (In Chinese)

43. Food and Agriculture Organization. Methodology and Guidelines for Fisheries Development Planning: With Special Reference to the Developing Countries in the African Region; FAO Fisheries Technical Paper No. 297; FAO: Rome, Italy, 1990.

44. The Geneva Conventions: Convention on Fishing and Conservation of the Living Resources of the High Seas; Convention on the High Seas; Convention on the Continental Shelf; Convention on the Territorial Sea and Contiguous Zone. 29 April 1958. Available online: https://www.un.org/Depts/los/convention_agreements/convention_historical_perspective.htm (accessed on 29 July 2021).

45. Xie, Y. A Commentary on the Present Fishing Regime on the High Seas. Peking Univ. Int. Comp. Law Rev. 2012, 9, 264-281. (In Chinese)

46. Friedman, K.; Garcia, S.M.; Rice, J. Mainstreaming Biodiversity in Fisheries. Mar. Policy 2018, 95, 209-220. [CrossRef]

47. Ostrom, E.; Burger, J.; Field, C.B.; Norgaard, R.B.; Policansky, D. Revisiting the Commons: Local Lessons, Global Challenges. Science 1999, 284, 278-282. [CrossRef] [PubMed]

48. Oude Elferink, A.G. Governance Principles for Areas beyond National Jurisdiction. Int. J. Mar. Coast. Law 2012, 27, 205-259. [CrossRef]

49. Wu, S. The Future of Global Ocean Governance and China's Option. Asia-Pac. Secur. Marit. Aff. 2020, 5, 1-22. (In Chinese)

50. McConnell, M.L. Observations on Compliance and Enforcement and Regional Fisheries Institutions: Overcoming the Limitations of the Law of the Seas. In Recasting Transboundary Fisheries Management Arrangements in Light of Sustainability Principles: Canadian and International Perspectives; Russell, D.A., VanderZwaag, D.L., Eds.; Martinus Nijhoff Publishers: Leiden, The Netherlands, 2010.

51. Juda, L. Changing Perspectives on the Oceans: Implications for International Fisheries and Oceans Governance. In Bringing New Law to Ocean Waters; David, D., Caron, H., Scheiber, N., Eds.; Martinus Nijhoff Publishers: Leiden, The Netherlands, 2004. 
52. Scovazzi, T. The Evolution of International Law of the Sea: New Issues, New Challenges. Collect. Courses Hague Acad. Int. Law 2000, 286, 39-244.

53. Bratspies, R.M. Finessing King Neptune: Fisheries Management and the Limits of International Law. Harv. Environ. Law Rev. 2003, 25, 213-258. [CrossRef]

54. Takei, Y. Filling Regulatory Gaps in High Seas Fisheries: Discrete High Seas Fish Stocks, Deep-Sea Fisheries, and Vulnerable Marine Ecosystems; Martinus Nijhoff Publishers: Leiden, The Netherlands, 2013.

55. United Nations Division for Ocean Affairs and the Law of the Sea. The Law of the Sea: The Regime for High-Seas Fisheries, Status and Prospects; Division for Ocean Affairs and the Law of the Sea, Office of Legal Affairs, United Nations: New York, NY, USA, 1992.

56. International Court of Justice. Fisheries Jurisdiction Case (Federal Republic of Germany v. Iceland), Merits, Judgement; I.C.J. Reports. 25 July 1974. Available online: https:/ / www.icj-cij.org/en/case/56 (accessed on 29 July 2021).

57. PSMA Parties Launch GIES Pilot Phase. Global Capacity Development Portal online. Available online: http://www.fao.org/ port-state-measures/news-events/detail/en/c/1403823/ (accessed on 16 July 2021). 